\title{
EFFECT OF CORN-SOYA DIET SUPPLEMENTED WITH COCKTAIL ENZYMES ON PERFORMANCE AND CARCASS CHARACTERISTICS' OF COBB BROILERS
}

\section{Kavitha R*, Chandrasekaran D}

Animal Feed Analytical and Quality Assurance Laboratory,

Veterinary College and Research Institute,Namakkal -637002

Received - October 22 2017; Revision - February 21, 2018; Accepted - May 05, 2018

Available Online - June 20, 2018

DOI: http://dx.doi.org/10.18006/2018.6(3).498.502

\section{KEYWORDS \\ Corn-soy diet \\ Carcass characteristics \\ NSP enzymes \\ Phytase \\ Production performance}

\begin{abstract}
Present study was conducted to access the effect of corn soya diet supplemented with cocktail enzymes on the performance and carcass characteristics of Cobb broilers. The cocktail enzyme consists of nonstarch polysaccharidase- Cellulases-333 IU/g; Xylanase - 1385 IU/g; Pectinase - 654 IU/g and Phytase$441 \mathrm{IU} / \mathrm{g}$. A total of 120 newly hatched Cobb broilers were distributed into four groups, the first treatment groups was kept as control, second group was fed with control diet supplemented with cocktail enzymes@250g/ton, third group was fed with control diet supplemented with cocktail enzymes@500g/ton and fourth group was fed with control diet supplemented with cocktail enzymes@1000g/ton. The birds were reared for a period of 42 days and production performance was assessed. No significant difference was reported in mean body weight of broilers fed on enzymes added and control diet. Similarly, in case of organs weight and intestinal length also, no significant difference was reported between the treatment containing enzymes groups and control group. Further, addition of enzymes significantly improved the feed efficiency than the control group. Hence, it can be concluded that addition of cocktail enzymes improved the feed taken efficiency of broilers.
\end{abstract}

* Corresponding author

E-mail: vetkavi2004@gmail.com (Kavitha R)

Peer review under responsibility of Journal of Experimental Biology and Agricultural Sciences.

Production and Hosting by Horizon Publisher India [HPI] (http://www.horizonpublisherindia.in/).

All rights reserved.
All the article published by Journal of Experimental Biology and Agricultural Sciences is licensed under a Creative Commons Attribution-NonCommercial 4.0 International License Based on a work at www.jebas.org.

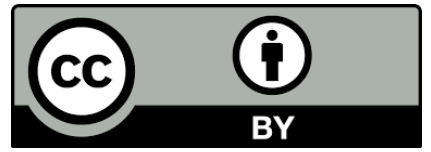




\section{Introduction}

Addition of non-starch polysaccharide (NSP) degrading enzymes in poultry diets has been followed for many years. However, the effects of exogenous enzymes can be variable and are depend on a large number of factors such as the age of the bird, the quality and type of diet (Olnood \& Liu, 2012). The use of exogenous enzymes to improve the digestibility of corn-soybean meal diets in broilers is not well documented. Neither corn nor soybean meal is regarded as viscous feedstuffs even though they do not contain appreciable amounts of NSPs. Corn contains approximately $0.9 \%$ soluble NSPs and 6\% insoluble NSP's, whereas, soybean meal contains approximately 6\% soluble NSP and $18-21 \%$ insoluble NSP (Bach Knudsen,1997). Further, Noy \& Sklan (1994) reported that ileal digestibility of corn starch rarely exceeds $85 \%$ in broilers between 4 and 21 day of age, indicating opportunities to further improve the digestibility of resistant starch in the jejunum and ileum through amylase supplementation. Addition on NSP degrading enzymes usually result in numerous beneficial effects, such as increased utilization of nutrients (e.g. fat and protein), improved AME values, increased growth rate, improved feed to gain ratio, decreased viscosity of intestinal digesta, reduced incidence of sticky excreta, improved litter condition and reduced environmental pollution due to a decreased output of manure and gases such as ammonia (Broz \&Ward 2007).

Enzyme supplementation can change the nutritional status and improve growth performance of broilers fed on corn-soya diet, but these are also closely related to the regulation of metabolism and functioning of the growth related endocrine system. Nutritional status is an important factor in the regulation of plasma hormones and intermediary metabolism in broiler chickens. Therefore, the objective of the study was to examine the effects of NSP enzyme supplementation on performance and carcass characteristics of broilers fed corn-soybean based diet.

\section{Materials and Methods}

A total of 120 newly hatched straight run broiler chicks (Vencobb 400) belonging to a single hatch were used for this experiment. The experiment was carried out as per the Institute Animal Ethics Committee (IAEC) and CPCSEA guidelines. The chicks were wing banded, weighed individually and distributed randomly to the four experimental diets with three replicates of ten chicks each. The treatments include as control (Fed on corn-soya diet only), control $+250 \mathrm{~g} /$ ton cocktail enzymes, control $+500 \mathrm{~g} /$ ton and control $+1000 \mathrm{~g} /$ ton cocktail enzymes. Here cocktail enzymes have a combination of non-starch polysaccharidase- Cellulases (333 IU/g); Xylanase (1385 IU/g); Pectinase (654 IU/g) and Phytase $(441 \mathrm{IU} / \mathrm{g})$. Feed ingredients were procured locally and used for the formulation of experimental broiler pre starter, starter and finisher diets. The ingredients and nutrient composition of broiler pre starter, starter, and finisher diets are presented in Table1. Feed intake, body weight were recorded at weekly intervals and weight gain and feed efficiency were worked out. Mortality, if any, was recorded at regular intervals. At the end of six week of age, birds were slaughtered as per the standard procedure to find out dressing percentage, the weights of gizzard, liver, heart, pancreas and intestinal length were measured and recorded. The data collected on various parameters were statistically analysed by one-way ANOVA as per the method of Snedecor \& Cochran (1989). The means were compared for significance by Duncan's multiple range test (1957).

\section{Results and Discussion}

The effects of enzyme supplementation on broilers at 10, 28 and 44 days are shown in the Table 2.The effect of multi enzyme preparation $(0,250,500$ and $1000 \mathrm{~g} / \mathrm{ton})$ of broiler diet was evaluated in terms of weight gain, feed intake, feed conversion ratio and carcass characteristics. The data on body weight, weight gain, feed intake and feed efficiency of broilers fed the diet added with different levels of enzymes are furnished in the Table 2 . The mean body weight gains among the experimental groups were 1942, 1992, 1998, and 2004g respectively at sixth week of age. Though a numerical increase in body weight gain was observed in enzyme added groups $250 \mathrm{~g}$, 500g and $1000 \mathrm{~g}$ but this weight gain was not significantly different. Result of present study are contradictory to the findings of Torres et al. (2004) who has observed that supplementation of enzyme at $500 \mathrm{~g} / \mathrm{ton}$ to the corn soya based diet not only improved body weight gain over the control, but also observed increased body weight gain in the groups fed with reduced protein diet after 21 days.

Reports of increased weight gain in broiler chicken due to the addition of NSP degrading enzymes either alone or in combination with phytase have been also recorded by $\mathrm{Wu}$ et al.(2004); Meng et al.(2005) and Woyengo et al. (2010). The mean feed intake of birds fed diets were 3756, 3610, 3631 and $3716 \mathrm{~g}$ for control, control $+250 \mathrm{~g}$, control $+500 \mathrm{~g}$, control $+1000 \mathrm{~g}$ respectively. A numerical reduction in the feed intake was noticed in the enzyme added groups when compared with the control. Similarly, Olnood \& Liu (2012) observed a significant $(\mathrm{P}<0.01)$ reduction in the feed intake in broilers. On the contrary $\mathrm{Wu}$ et al. (2004) observed that addition of xylanase and phytase alone or in combination to wheat-based broiler diet increased the feed consumption by 10.8-13.5 per cent over the control group. Similarly, Meng et al. (2005) in their 19 days broiler trial observed supplementation of carbohydrases either alone or in combination to wheat soya based diet increased the feed intake numerically by $1.2-2.8$ per cent. The mean feed efficiency (feed/gain) showed significant difference among the various treatments and the efficiency among the various groups were $1.93,1.82,1.82$ and 1.85 respectively. The enzyme added groups 
Table 1 Ingredient and nutrient composition of experimental diets for different periods of the experiment

\begin{tabular}{|c|c|c|c|}
\hline Maize & 44.5 & 48.84 & 51.31 \\
\hline Soy bean meal (CP 46\%) & 41.25 & 36.6 & 32.68 \\
\hline Fish meal & 6 & 6 & 6 \\
\hline Rice bran oil & 5.4 & 5.77 & 7.37 \\
\hline Di-calcium phosphate & 1.25 & 1 & 1.05 \\
\hline Calcite & 0.83 & 1.03 & 1.03 \\
\hline L-Lysine (g/100kg) & 49.29 & 118 & 76.85 \\
\hline DL-methionine $(\mathrm{g} / 100 \mathrm{~kg})$ & 230 & 234 & 91.16 \\
\hline Salt (g/100kg) & 258.47 & 338.03 & 318.04 \\
\hline Sodium bicarbonate $(\mathrm{g} / 100 \mathrm{~kg})$ & 206.73 & 38.58 & 51.46 \\
\hline Additives \& supplements (g/100kg) & 630 & 630 & 630 \\
\hline \multicolumn{4}{|l|}{ Nutrient Composition (\%) } \\
\hline Dry matter & 93.08 & 92.3 & 93.01 \\
\hline Crude protein & 23.01 & 21.49 & 20 \\
\hline Crude fibre & 4.25 & 4.05 & 3.85 \\
\hline NDF & 10.77 & 11.42 & 10.32 \\
\hline ADF & 1.92 & 1.49 & 1.61 \\
\hline Hemicellulose & 8.84 & 9.41 & 9.51 \\
\hline Cellulose & 1.78 & 1.22 & 1.84 \\
\hline Lignin & 0.14 & 0.24 & 0.42 \\
\hline Ether extract & 6.5 & 6.96 & 9.18 \\
\hline Total ash & 8.51 & 8.21 & 8.34 \\
\hline $\mathrm{NFE}^{*}$ & 57.73 & 59.29 & 58.63 \\
\hline Acid insoluble ash & 2.31 & 2.41 & 2.51 \\
\hline Calcium & 1.01 & 0.99 & 0.99 \\
\hline Available phosphorus & 0.5 & 0.45 & 0.45 \\
\hline Lysine* & 1.3 & 1.25 & 1.12 \\
\hline Methionine* & 0.58 & 0.56 & 0.4 \\
\hline Cystine + Methionine* & 0.93 & 0.9 & 0.72 \\
\hline Metabolizable energy*(kcal/kg) & 3050 & 3125 & 3250 \\
\hline
\end{tabular}

Mineral mixture added at the level per $\mathrm{kg}$ feed supplied manganese (81 mg), zinc (78 mg), iron (30 mg), iodine (3mg), copper ( $3 \mathrm{mg})$ and cobalt (1.5mg). Vitamin $A B_{2} D_{3} K$ added at the level per $\mathrm{kg}$ feed supplied vitamin $A(16500 \mathrm{IU}), B_{2}(10 \mathrm{mg}), \mathrm{D}_{3}(3200 \mathrm{IU})$ and vitamin $\mathrm{K}(2 \mathrm{mg})$.Vitamin $B$ complex added at the level per $\mathrm{kg}$ feed supplied, thiamine (2.8 $\mathrm{mg})$, pyridoxine (5.6 $\mathrm{mg})$, niacin $(42 \mathrm{mg})$, cyanocobalamine $(28 \mathrm{mcg})$, vitamin $\mathrm{E}$ $(28 \mathrm{mg})$, calcium D pantothenate $(28 \mathrm{mg})$ and folic acid $(2.8 \mathrm{mg})$, calcium $(30.1 \mathrm{mg})$ coccidiostat added at the level per $\mathrm{kg}$ feed supplied $125 \mathrm{mg}$ of di-nitro-ortho-toluamide. Antibiotic (Oxy tetracycline) $0.5 \mathrm{~g}$ was added per $\mathrm{kg}$ of feed. $*$ Calculated values. 
Table 2 Effects of enzyme supplementation on body weight gain, feed intake and FCR in broiler chicks

\begin{tabular}{|cccc|}
\hline Treatments & Weight gain $(\mathrm{g})$ & Feed intake $(\mathrm{g})$ & Feed conversion ratio \\
\hline Control & $1942.50 \pm 39.51$ & $3756.53^{\mathrm{a}} \pm 9.67$ & $1.93^{\mathrm{a}} \pm 0.001$ \\
\hline Control $+250 \mathrm{~g}$ & $1992.43 \pm 46.96$ & $3610.50^{\mathrm{b}} \pm 22.25$ & $1.82^{\mathrm{b}} \pm 0.01$ \\
\hline Control $+500 \mathrm{~g}$ & $1998.83 \pm 43.14$ & $3631.10^{\mathrm{b}} \pm 3.83$ & $1.82^{\mathrm{b}} \pm 0.01$ \\
\hline Control $+1000 \mathrm{~g}$ & $2004.73 \pm 40.04$ & $3716.67^{\mathrm{a}} \pm 10.84$ & $1.85^{\mathrm{b}} \pm 0.01$ \\
\hline P-value & 0.345 & 0.031 & 0.027 \\
\hline
\end{tabular}

Means with at least one common superscript in a column did not significantly differ $(P>0.05)$

Table 3 Effect of different levels of enzymes addition on carcass characteristics in broilers

\begin{tabular}{|cccccc|}
\hline Treatments & Dressing percentage & $\begin{array}{c}\text { Gizzard } \\
(\mathrm{g}) / \mathrm{kg} \text { of live weight }\end{array}$ & $\begin{array}{c}\text { Liver } \\
(\mathrm{g}) / \mathrm{kg} \text { of live weight }\end{array}$ & $\begin{array}{c}\text { Heart } \\
(\mathrm{g}) / \mathrm{kg} \text { of live weight }\end{array}$ & $\begin{array}{c}\text { Pancreas } \\
(\mathrm{g}) / \mathrm{kg} \text { of live weight }\end{array}$ \\
\hline Control & $75.48^{\mathrm{b}} \pm 0.91$ & $16.44 \pm 0.41$ & $19.84 \pm 1.07$ & $3.72 \pm 0.40$ & $1.90 \pm 0.14$ \\
\hline Control $+250 \mathrm{~g}$ & $74.65^{\mathrm{b}} \pm 1.21$ & $16.04 \pm 0.44$ & $20.50 \pm 1.60$ & $4.02 \pm 0.16$ & $2.10 \pm 0.15$ \\
\hline Control $+500 \mathrm{~g}$ & $78.24^{\mathrm{a}} \pm 0.50$ & $15.40 \pm 0.30$ & $20.56 \pm 0.77$ & $4.09 \pm 0.20$ & $1.85 \pm 0.12$ \\
\hline Control $+1000 \mathrm{~g}$ & $74.30^{\mathrm{b}} \pm 0.48$ & $14.85 \pm 0.46$ & $17.03 \pm 0.71$ & $3.78 \pm 0.25$ & $1.78 \pm 0.07$ \\
\hline P-value & 0.042 & 0.845 & 0.249 & 0.521 & 0.301 \\
\hline
\end{tabular}

Means with at least one common superscript in a column did not significantly differ $(\mathrm{P}>0.05)$

Table 4 Effect of different levels of enzymes addition on intestinal length in broiler chickens

\begin{tabular}{|cccc|}
\hline Treatments & Small intestine length (cm/kg body wt) & Caecum length (cm/kg body wt) & Colo- rectum length (cm/kg body wt) \\
\hline Control & $88.59^{\mathrm{a}} \pm 3.87$ & $17.91^{\mathrm{a}} \pm 0.86$ & $4.34 \pm 0.52$ \\
\hline Control+250g & $90.87^{\mathrm{a}} \pm 2.47$ & $16.90^{\mathrm{a}} \pm 0.67$ & $3.94 \pm 0.40$ \\
\hline control+500g & $89.15^{\mathrm{a}} \pm 3.95$ & $15.53^{\mathrm{b}} \pm 0.71$ & $3.96 \pm 0.30$ \\
\hline control+1000g & $85.11^{\mathrm{b}} \pm 3.12$ & $17.46^{\mathrm{a}} \pm 0.23$ & $4.26 \pm 0.23$ \\
\hline P-value & 0.039 & & \\
\hline
\end{tabular}

Means with at least one common superscript in a column did not differ significantly ( $\mathrm{P}>0.05)$

recorded a better feed efficiency than the control. The carcass characteristics in terms of dressing percentage, weights of gizzard, liver, heart and pancreas are presented in Table 3.

Dressing percentage of different treatment groups was 75.48 (control), 74.65 (control+250g), $78.24 \quad$ (control+500g) and $74.30 \%$ (control $+1000 \mathrm{~g}$ ). No consistent pattern could be observed in the dressing percentage in the various treatment groups, even though control $+500 \mathrm{~g}$ cocktail enzymes fed broilers have significantly $(\mathrm{P}<0.05)$ higher dressing percentage as compared to the control. Balamurugan (2004) observed no significant difference in dressing percentage of broilers fed with corn soya based diet supplemented enzymes. The mean weight ( $\mathrm{g} / \mathrm{kg}$ of live weight) of gizzard, liver, heart and pancreas of the birds fed diets among the groups were presented in Table 3. No significant difference in organs weight was observed between the control and enzyme added groups. Similarly, Balamurugan (2004) observed no significant difference in the weight of giblets due to supplementation of NSP degrading enzymes alone or in combination with phytase to corn soya based broiler diet. The mean length of different segments of intestine is presented in the Table 4.Variation was observed in the mean length $(\mathrm{cm} / \mathrm{kg}$ body weight) of small intestine between the different treatment groups. A numerical increase in the length of the small intestine was 
observed in the broiler fed on $250 \mathrm{~g}$ and $500 \mathrm{~g}$ cocktail enzymes while a reduction in length was observed in broiler fed on $1000 \mathrm{~g}$ cocktail enzymes as compared to control.

Similar to small intestine length the mean length $(\mathrm{cm} / \mathrm{kg}$ body weight) of caecum also varied among the treatment groups, but there was no significant difference when compared to the control. Colo-rectum length did not differ significantly between enzyme added groups and control group. Similarly, Balamurugan (2004) in his trial in broilers, fed with corn soya diet, though observed decreased length in the entire enzyme added groups, the differences were not significant. But Wang et al. (2005) observed a linear decrease in the length of ileum with the increase in the level of enzyme in the wheat based diet of broilers.

\section{Conclusions}

There was no significant difference in weight gain between the control and enzymes added groups. From this study, it could be concluded that the addition of combination of non-starch polysaccharidase enzyme with phytase at $250 \mathrm{~g} / \mathrm{ton}$ of feed improved the feed efficiency in broilers.

\section{Acknowledgments}

The authors are thankful to the Dean, Veterinary College and Research Institute, Namakkal and Director of Centre for Animal Production Studies, TANUVAS, Chennai for providing necessary facilities to carry out the present experiment.

\section{Conflict of Interest}

Authors declare that there is no conflict of interests arising from this study.

\section{References}

Bach Knudsen KE (1997) Carbohydrate and lignin contents of plant materials used in animal feeding. Animal Feed Science and Technology 67: 319-338.

Balamurugan R (2004) Performance and intestinal response of broiler chickens fed on multi enzyme supplemented diet. M.V.Sc., thesis, submitted to Tamil Nadu Veterinary and Animal Sciences University, Chennai.
Broz J, Ward NE (2007) The role of vitamins and feed enzymes in combating metabolic challenges and disorders. Journal of Applied Poultry Research 16: 150-159.

Duncan DB (1955) Multiple range and multiple F test. Biometrics 11: $1-42$.

Meng X, Slominski BA, Nyachoti CM, Campbell LD, Guenter W (2005) Degradation of cell wall polysaccharides by combinations of carbohydrase enzymes and their effect of nutrient utilization and broiler chicken performance. Poultry Science 84: 37-47.

Noy Y, Sklan D (1994) Digestion and absorption in the young chick. Poultry Science 73: 366-373.

Olnood CG, Liu YG (2012) Effect of multi-NSP enzymes and phytase combination on growth performance of broiler chickens fed with different quality grades of ingredients. Australian Poultry Science Symposium 23: 287-290.

Snedecor GW, Cochran WG (1989) Statistical Methods, $8^{\text {th }}$ Edn. Iowa State University Press, Ames, Iowa.

Torres DM, De Cotta JT, Teixeira AS, Fonseca JA, Da Fonseca RA, Dos Santos EC, Alves EL(2004) Corn and soybean meal based diets supplemented with enzymes in feed of broiler chickens. Nutrition Abstract and Reviews B74: 1415.

Wang ZR, Qiao SY, Lu WQ, Li DF (2005) Effects of enzyme supplementation on performance, nutrient digestibility, gastrointestinal morphology, and volatile fatty acid profiles in the hindgut of broilers fed wheat-based diets. Poultry Science 84:875881.

Woyengo TA, Slominski BA, Jones RO (2010) Growth performance and nutrient utilization of broiler chickens fed diets supplemented with phytase alone or in combination with citric acid and multicarbohydrase. Poultry Science 89: 2221-2229.

Wu YB, Ravindran V, Thomas DG, Birtles MJ, Hendriks WH (2004) Influence of phytase and xylanase, individually or in combination, on performance, apparent metabolizable energy, digestive tract, measurements and gut morphology in broilers fed wheat-based diets containing adequate level of phosphorus. British Poultry Science 45: 76-84. 